\title{
The Agribusiness Model of Natural Silk System in Soppeng Regency
}

\author{
Mardia \\ Universitas Indonesia Timur \\ Makassar, Indonesia
}

\author{
Nisma Iriani \\ Universitas Indonesia Timur \\ Makassar, Indonesia
}

\author{
Kamaluddin \\ Universitas Indonesia Timur \\ Makassar, Indonesia
}

\begin{abstract}
This study aims to determine how natural silk business development in the village Solie Soppeng Regency through the implementation of agribusiness and the extent of natural silk farmers' income systems. This research used a qualitative approach. The results showed that natural silk business in Soppeng supported with community institutions such as farmers' groups, cooperatives, and entrepreneurs. The activities of farmers in the production aspect with cultivation on vacant land, homestead and as a hedge. Counseling and mentoring from the government to support agribusiness activities. Marketing aspects of the cultivation of silkworms were limited to the natural silk industry which is an export commodity.
\end{abstract}

\section{Keywords - Natural silk; agribusiness; silkworm}

\section{INTRODUCTION}

Natural fibres made from plants and animals used to manufacture textile materials such as cotton and silk fibres [1]. Silk fibres are sourced from material silkworms of mulberry trees. The cultivation of silkworm (sericulture) has been carried out in China since 2,000 years ago. Practically, the growing of silkworm is environmentally friendly in Asia. Sericulture agribusiness systems contribute to rural residents' income in the agricultural sector either primary or secondary source. This method involves the workers of all ages and gender. [2].

Indonesia has significant potential to produce natural silk fibres. Natural conditions and the environment in Indonesia is also quite favourable for the cultivation of silkworms. One agricultural commodity from forestry subsector that has the potential to be developed is a commodity of natural silk. These products have long been grown in South-Sulawesi community, but handling is not done professionally to it. The system of agribusiness in silkworm increase the product quality and the wealth of farmers.

Silkworm business is a home industry supported by simple technology and high economic value. This activity supports land rehabilitation and soil conservation efforts. With the cultivation of silkworms, the optimization of land-productivity can be achieved.

Business silkworm an agroindustrial activity that includes two interrelated aspects, namely cultivation aspects and aspects of the industry. Aspects include the cultivation of mulberry planting effort as feed silkworm breeding silkworms and caterpillars maintenance activities to form a cocoon ready for harvest. While aspects of the industry include the processing of cocoons into yarn, weaving until it becomes silk.

The issues of silkworm cultivation in several countries due to lack of public knowledge about the management of silkworms. Agribusiness management involves several contributing factors, such as land, capital, infrastructure and workforce. The same condition In Madagascar, most of the villagers did not know what the silkworm and only a few know that silk can be used to produce textiles. [3].

Communities in Soppeng also develop business silkworms as an economic activity. Natural silk cultivation prepared traditionally since the $1950 \mathrm{~s}$ based on knowledge from generation to generation. The maintenance of silkworm strengthen the local economy and relatively can be done by all family members. This study aims to assess the development efforts in natural silk agribusiness through agribusiness system that is focused on silkworm cultivation activities in Soppeng.

\section{METHOD}

This study is a survey research with a qualitative approach. The focus of the investigation at the District Donri-Donri, Soppeng involving ten producers of natural silkworms as informants. Data collection methods with an in-depth interview conducted in December 2015 until March 2016. The Agribusiness model defines as several aspects that affected the silkworm production.

\section{RESULTS AND DISCUSSION}

\section{A. Results}

The series of activities on natural silk agribusiness system shown in Figure 1. The result of the sericulture is cocoon or pupa house is woven from series of the filament. Many factors determined the quality of cocoon the nature of heredity, silkworm types, circumstances during maintenance, the transfer of silkworm to the cocoon container, environment and quality feed and feeding methods.

In the cultivation of silkworms, farmers experience various technical and non-technical barriers. Many efforts to increase production such as:

\section{Intensification and extensification of plants.}


2. Application of production techniques and pest control. Also, improvements in the system of silkworm maintenance.

3. Increased workforce capacity for land clearing and construction.

4. The increased skill of silkworm cultivation.

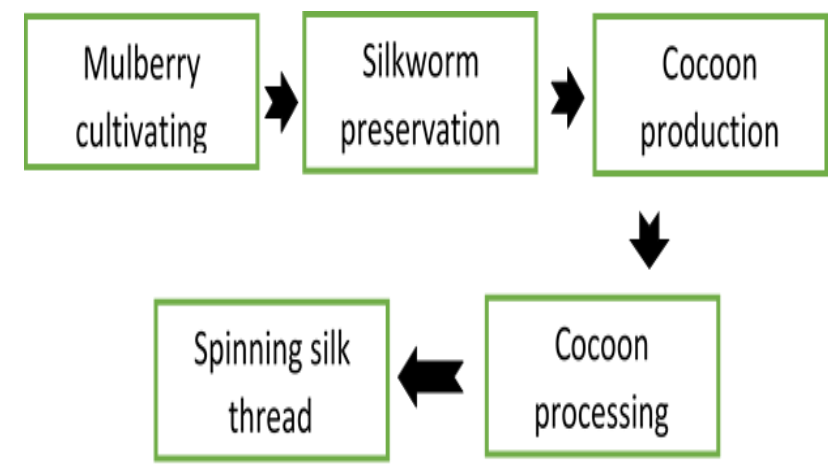

Fig. 1. Agribusiness activities of silkworm in Soppeng Regency

The quality of cocoons is strongly influenced by the quality of mulberry seedlings and cultivation. Conventional maintenance that does not take into account the cleanliness of the cage. The quality of the cocoon contributes to the quality of the yarn, so farmers should strive to maintain the quality of the cocoon. The determinants of cocoon quality include heredity, silkworm type, condition during maintenance, time of caterpillar removal on the tool of cocoon product environment and feed quality and method of feeding silkworm

Sub-systems in silk business are institutional farmers, production, supporting facility, capital, and entrepreneur.

Silkworm agribusiness system involves farmers with traditional techniques. This method involves farmer groups and farmers. Table 1 illustrates the planting area, the number of farmers' groups and the number of farmers silkworms in Soppeng.

TABLE I. DESCRIPTION OF SILKWORM CULTIVATION IN SOPPENG REGENCY

\begin{tabular}{|c|c|c|c|}
\hline Year & $\begin{array}{c}\text { Planting } \\
\text { area (ha) }\end{array}$ & $\begin{array}{c}\text { Number of farmer } \\
\text { group }\end{array}$ & $\begin{array}{c}\text { Number of } \\
\text { farmers }\end{array}$ \\
\hline 2007 & 639 & 21 & 816 \\
\hline 2008 & 550 & 22 & 758 \\
\hline 2009 & 525 & 20 & 735 \\
\hline 2010 & 550 & 22 & 758 \\
\hline 2011 & 84,46 & 4 & 179 \\
\hline 2012 & 96 & 7 & 158 \\
\hline
\end{tabular}

Based on data table 1, the number of silkworm farmers decreased with the decline of planting area. The institutional farmer in Soppeng Regency about silkworm agribusiness is farmers group. Farmers group is social institutions which serve as a communication forum among farmers. Farmers institutions made discussion by informal meeting related to problems such as seedling cultivation, planting, harvesting, and pest.

In the aspect of the production, cultivation of mulberry developed by the community on vacant land, home gardens and some are used as a hedge and barrier mud on the river border. The number of plants per hectare varies depending mulberry planting distance. Mulberry planting pattern is seen in the study site in the form of monoculture and those that shaped intercropping. Moreover, pest and disease risk greater in monoculture system, but this system promises a higher sale value.

Infrastructure to support the farmer in the form of technical and extension services related to the development of production technology. Also, the promotion of the silk as leading trade products be other supporting the facilities and infrastructure. In marketing aspects of the cultivation, silkworms were limited to the natural silk industry which is an export commodity. By it the growing of silkworms can support foreign exchange income, labour-intensive, have a very close relationship with other sectors.

Silkworm farmer entrepreneurs are communicating with each other once a week minimum to solve their problems. Cooperative institutions are financial organizations locally sourced from members. Development of livestock enterprises silkworm silk is supported by businessmen from Wajo as a party to utilize its production.

\section{B. Discussion}

The pattern of natural silk farmers' indicated that effort as natural silk centre with small-scale, simple technology and low capital levels. Nevertheless, agribusiness is also experiencing problems, namely the shift of mulberry farmers in other plantation business. Moreover, the marketing aspect of corporate silk is not currently experiencing barriers and supported by the efforts of silk gloves. The use of silk fabric is not limited to clothing but has expanded to the needs of nonclothing such as textiles and interior decorating hotels and other offices.

The biggest obstacle is the lack of processing aspects of public knowledge about maintenance and harvesting. Another obstacle is financing business aspects of natural silk in the study site come from a variety of sources, namely: Banking, Cooperatives, Entrepreneur, partner business group. Aspects of business financing have not been too difficult for the business group is still small scale so that the required capital is not too big. Technical assistance for a local farmer can increase the motivation and their self-concept to cultivate the mulberry as support of silk industry.[4].

The previous research revealed that the aspects of the production are an important part of agribusiness for $13 \%$ percent of the financing system technology and $16 \%$ of labour costs. ([5]. In contrast to agribusiness silkworms, funding of labour is not a problem, because this business is not the cost of labour and only done by family members. 


\section{CONCLUSION}

Natural silk business in Soppeng supported with community institutions such as farmers' groups, cooperatives, and entrepreneurs. The activities of farmers in the production aspect with cultivation on vacant land, homestead and as a hedge. Counseling and mentoring from the government to support agribusiness activities. Marketing aspects of the cultivation of silkworms were limited to the natural silk industry which is an export commodity.

\section{References}

[1] F. Mohammad, 'Sustainable Natural Fibres from Animals, Plants and Agroindustrial Wastes-An Overview', in Sustainable Fibres for Fashion Industry, Springer, 2016, pp. 31-44.

[2] T. Attathom, 'Eri Silkworm, Philosamia ricini (Lepidoptera: Saturniidae)', in Encyclopedia of Entomology, Springer, 2004, pp. 800802.

[3] T. Razafimanantosoa, O. R. Ravoahangimalala, and C. L. Craig, 'Indigenous silk moth farming as a means to support Ranomafana National Park', Madagascar Conserv. Dev., vol. 1, no. 1, 2006.

[4] S. J. Torok and A. Schroeder, 'A comparison of problems and technical assistance needs of small agribusiness and nonagribusiness firms', Agribusiness, vol. 8, no. 3, pp. 199-217, 1992.

[5] J. G. Beierlein, K. C. Schneeberger, and D. D. Osburn, Principles of agribusiness management. Waveland Press, 2013. 